\title{
Kajian Yuridis Perbuatan Melawan Hukum Sebagai Faktor Pembatalan Lelang Atas Objek Jaminan
}

\author{
Jordy Herry Christian \\ Mahasiswa Fakultas Hukum, Universitas Negeri Semarang \\ Jl. Kampus Timur, Sekaran, Gunungpati, Kota Semarang, Jawa Tengah 50229
}

Surel: jordy31798@gmail.com

\begin{abstract}
ABSTRAK
Kajian yuridis onrechtmatige daad sebagai faktor untuk terjadinya pembatalan atas lelang objek jaminan hak tanggungan meninjau ada tidaknya $\mathrm{PMH}$ (onrechtmatige daad) yang dilakukan oleh kreditur terhadap debitur dalam pelaksaan lelang eksekusi objek hak tanggungan. Kajian ini tidak terlepas dari pasal 1365 Burgerlijk Wetboek yang diratifikasi menjadi KUH Perdata yang memuat 4 syarat atau unsur dari onrechtmatige daad, yaitu harus adanya perbuatan (daad), kesalahan (schuld), kerugian (shade) dan kausalitas (causality). Salah satu dalil yang modern ini sering digunakan debitur untuk melakukan pembatalan lelang objek hak tanggungan adalah penetapan nilai atau harga limit yang rendah yang tidak sesuai dengan ketentuan pelaksanaan dari lelang. Sebagaimana contoh riil atas penetapan nilai atau harga limit sebagai faktor pembatalan atas lelang dapat kita temui dalam Putusan Mahkamah Agung No 274/ PDT.G/ 2013 /PN.BDG yang didalamnya debitur mendalilkan adanya perbuatan melawan hukum yang dilakukan oleh kreditur atau tergugat sehingga hakim menyatakan lelang tersebut sebagai tidak sah dan tidak memiliki kekuatan hukum mengikat, hal ini dikarenakan pelaksanaan lelang tersebut tidak memenuhi ketentuan lelang di dalam PMK Nomor 27/PMK.06/2016,sehingga risalah lelang atas objek jaminan tersebut dibatalkan oleh hakim dalam putusannya dan
\end{abstract}

RIWAYAT ARTIKEL

Article History

Diterima : 11 September 2019

Dipublikasi : 25 November 2019

\section{KATA KUNCI}

Keywords

hukum, pembatalan, lelang

\section{HOW TO CITE (saran perujukan):}

Christian, J.D. (2019). "Kajian Yuridis Perbuatan Melawan Hukum Sebagai Faktor Pembatalan Lelang Atas Objek Jaminan", Lex Scientia Law Review. Volume 3 No. 2, November, hlm. 205-218 


\section{PENDAHULUAN}

Pembangunan nasional merupakan Negara Indonesia yang dapat dicapai melalui pembangunan dibidang ekonomi, sangat diperlukan dana yang digunakan sebagai modal dalam jumlah besar bagi masyarakat sebagai orang perseorangan dan badan hukum. Seiring meningkatnya kegiatan pembangunan, maka hal ini juga mempengaruhi peningkatan keperluan akan tersedianya dana, yang masyarakat modern ini memilih untuk memperoleh dana tersebut melalui kegiatan perkreditan. Tetapi tidak jarang dalam kegiatan perkreditan terjadi wanprestasi atau tidak terjadi pemenuhan kewajiban oleh debitur yang berimplikasi pada pengeksekusian objek jaminan yang dijaminkan oleh debitur kepada kreditur untuk mendapatkan dana tersebut. Eksekusi yang dilakukan oleh kreditur tidak terlepas dari upaya pemenuhan dan pengembalian hak kreditur. Kreditur dalam melaksanakan eksekusi tersebut haruslah melalui sebuah lembaga umum, yaitu lembaga lelang. Lembaga lelang merupakan lembaga hukum yang modern ini dibutuhkan oleh masyarakat luas. Lembaga lelang sendiri memiliki salah satu fungsi untuk melaksanakan lelang eksekusi apabila terjadi permasalahan antara kreditur sebagai pihak yang meminjamkan dana dan debitur sebagai pihak yang meminjam dana dalam lingkup jaminan. Dalam perjanjian jaminan, wewenang kreditur adalah untuk mengeksekusi objek jaminan debitur. Tetapi perlindungan hukum tidak hanya diberikan kepada kreditur, tetapi juga diberikan kepada debitur dalam hal pembatalan lelang eksekusi atas objek jaminan. Perlindungan ini merupakan pencegahan terjadinya perbuatan kreditur yang merugikan debitur dalam hal lelang eksekusi objek jaminan seperti penetapan nilai jual objek pajak dengan nilai limit yang terlalu rendah dan proses pelelangannya tidak sesuai dengan ketentuan lelang. Apabila debitur menjumpai kondisi demikian, maka debitur dapat membatalkan hasil lelang atas objek jaminan apabila kreditur terbukti melakukan perbuatan melawan hukum atas dasar putusan hakim yang didahului dengan debitur mengajukan gugatan ke Pengadilan Negeri yang berkompetensi. Gugatan oleh debitur ini secara umum dilator belakangi oleh rasa ketidakpuasan. Dilansir dari BMKN Nomor 14 Tahun 2013, jumlah gugatan yang ditujukan kepada DJKN atau KPKNL adalah 2.458 (Khalim, 2014). Gugatan itu didasari berbagai motif dan alasan ,serta gugatan tersebut diajukan secara bervariasi ,baik pada saat sebelum lelang, pada saat pelaksanaan lelang dan pascalelang . Dari 2458, 1500 lebih diantara gugatan tersebut yang menggunakan dalil PMH atau onrechtmatige daad sebagai dasar gugatannya. PMH yang didalilkan memiliki karakteristik yang berbeda beda, seperti diantaranya gugatan sebelum pelaksaan lelang dan terdapat juga gugatan pascalelang. Salah satu dalil yang banyak digunakan untuk menyatakan adanya onrechtmatige daad adalah penetapan atas nilai limit atas lelang objek hak tanggungan yang rendah, untuk memberi kejelasan maka penulis dalam hal ini mengambil contoh Putusan No.274/ PDT.G/ 2013 /PN.BDG yang 
didalamnya mendalilkan penetapan nilai limit lelang objek hak tanggungan yang rendah dan dalam putusannya majelis hakim menyatakan adanya perbuatan melawan hukum (onrechtmatige daad) dalam penetapan nilai limit atas lelang objek hak tanggungan yang tidak dapat dipertanggungjawabkan dan melawan hukum.

\section{Rumusan Masalah}

1. Bagaimana kajian yuridis dalam menentukan adanya onrechtmatige daad dalam gugatan pelaksaan lelang?

2. Bagaimana kajian yuridis terhadap Putusan No.274 /PDT.G/ 2013/PN.BDG dalam menetapkan nilai limit rendah sebagai faktor pembatalan lelang atas dasar putusan hakim?

\section{Metode Penulisan}

Metode penelitian dalam menulis jurnal ini difokuskan dengan metode yuridis normatif, metode yang dipilih oleh penulis merupakan penelitian melalui pendekatan Undang-Undang (Ibrahim, 2006:295). Penelitian ini difokuskan untuk mengetahui tindakan-tindakan apa yang dapat menentukan suatu perbuatan merupakan perbuatan melawan hukum dalam gugatan pelaksaan yang dapat dipergunakan oleh debitur sebagai dasar gugatan ke pengadilan sehingga perbuatan melawan hukum (onrechtmatige daad) terkhusus penetapan nilai atau harga limit yang rendah dapat menjadi dasar pembatalan lelang atas putusan hakim dan untuk menganalisa kajian yuridis terhadap Putusan Mahkamah Agung Nomor 274 Tahun 2013 dalam menentukan onrechtmatige daad sebagai faktor pembatalan lelang atas objek jaminan atas dasar putusan hakim.

\section{PEMBAHASAN}

\section{A. Kajian Yuridis Dalam Menentukan Onrechtmatige Daad Dalam Gugatan Pelaksanaan Lelang}

Indonesia sebagai rechtstaat memberikan perlindungan berupa upaya hukum kepada masyarakatnya, upaya hukum ini dapat dilakukan oleh warga negaranya apabila terdapat suatu ketidakpuasaan melalui gugatan, atau dalam hal ini adalah gugatan pelaksaan lelang yang mayoritas disebabkan oleh onrechtmatige daad. Penentuan ada tidaknya perbuatan melawan hukum tidak terlepas dari klausa pasal 1365 Burgerlijk Wetboek Indonesia yang berbunyi:

"Tiap perbuatan yang melanggar hukum dan membawa kerugian kepada orang lain, mewajibkan orang yang menimbulkan kerugian itu karena kesalahannya untuk menggantikan kerugian tersebut."

Dari klausa pasal 1365 Burgerlijk Wetboek Indonesia tersebut, kita dapat menyimpulkan secara singkat bahwa untuk menyatakan onrechtmatige daad harus memenuhi unsur kumulatif ,yaitu adanya perbuatan (daad), kesalahan (schuld), 
kerugian (schade), dan kausalitas (causality) . Dalam pengertian secara sempit, perbuatan melawan hukum atau onrechtmatige daad dapat diartikan bahwa orang yang melakukan perbuatan pelanggaran terhadap orang lain atau dia telah berbuat sesuatu yang bertentangan dengan kewajiban hukumnya sendiri (Volmar, 2004: 184). Secara terminologi, pengertian dari "Perbuatan Melawan Hukum" adalah terjemahan dari kata onrechtmatige daad, yang dapat kita jumpai dalam Burgerlijk Wetboek Buku Ketiga tentang Perikatan (Prayogo, 2016: 281).

Di negeri Belanda, perkembangan sejarah tentang pengertian onrechtmatige daad terbagi menjadi tiga periode waktu, yaitu: (Febriliana, 2017: 12).

a. Sebelum tahun 1838

Pada periode ini, terdapat kodifikasi pada tahun 1838 yang membawa perubahan besar terhadap pengertian onrechtmatige daad yang pada periode ini PMH diartikan sebagai on wetmatigedaad (perbuatan yang melanggar UU) yang memiliki artian bahwa perbuatan tersebut sebatas hanya bertentangan dengan UU yang berlaku.

b. Pada Tahun 1838 sampai dengan 1919

Pada periode waktu ini, pengertian PMH (onrechtmatige daad) menjadi lebih luas dari sebelumnya, sehingga dapat mencakup pelanggaran terhadap hak subjektif. Pada pasal 1365 Burgerlijk Wetboek Indonesia diartikan sebagai perbuatan atau tindakan yang melawan hukum atau disebut juga dengan culpa in committendo. Sedangkan dalam Pasal 1366 Burgerlijk Wetboek Indonesia diartikan sebagai perbuatan melawan hukum dengan cara melalaikan atau yang disebut juga dengan culpa in ommittendo.

c. Setelah tahun 1919

Pada periode waktu ini, juga terjadi penafsiran luas terhadap PMH pada pasal1365 KUHPer Indonesia melalui putusan Hoge Raad. Pengertian PMH (onrechtmatige daad) pada periode ini tidak hanya sebatas melakukan pelanggaran terhadap peraturan perundang-undangan yang tertulis ,tetapi juga termasuk didalamnya perbuatan yang melanggar hak orang lain yang telah dijamin hukum dapat dikategorikan sebagai PMH (onrechtmatige daad), selain itu perbuatan yang bertentangan dengan kesusilaan dan yang bertentangan dengan kewajiban pelaku, serta yang bertentangan dengan sikap yang baik dalam masyarakat untuk memperhatikan kepentingan orang lain dapat dikategorikan sebagai PMH (onrechtmatige daad) karena pengertian PMH (onrechtmatige daad)mengalami perluasan .

Untuk mengkaji apakah suatu perbuatan (daad) tersebut dapat dinyatakan sebagai suatu perbuatan yang melawan hukum (onrechtmatige daad), maka syarat yang harus terpenuhi adalah :

\section{Perbuatan (daad)}


Secara luas pengertian dari adanya perbuatan melawan hukum adalah perbuatan tersebut melanggar peraturan yang berlaku . Perbuatan dalam hal ini terbagi menjadi 2 ,yaitu perbuatan yang tampak secara aktif dan tidak aktif. Dalam PMH, tidak terdapat unsur yang menandakan adanya "persetujuan atau kata sepakat" dan tidak terdapat juga unsur yang menandakan "causa yang diperbolehkan". Dalam perkara lelang , onrechtmatige daad biasa ditujukan kedalam suatu pengertian dimana adanya penetapan nilai limit atau harga lelang yang terlalu rendah dibawah nilai jual objek pajak sehingga bertentangan dengan asas kepatutan, asas kewajaran dan juga melanggar hak pemilik atas barang. Selain itu juga bertentangan dengan kewajiban hukum bagi kreditur selaku penjual untuk mengoptimalkan harga jual lelang (nilai limit) sesuai dengan PMK, yang akhirnya bertentangan juga dengan kepatutan dalam masyarakat (Fuady, 2013: 10). Perluasan definisi dari onrechtmatige daad juga memiliki artian bahwa perbuatan tersebut tidak hanya melanggar peraturan perundangundangan yang tertulis ,tetapi juga termasuk didalamnya pelanggaran hak ,kewajiban ,kesusilaan dan norma.

\section{Adanya Kesalahan (schuld)}

Syarat kedua yang harus dipenuhi adalah adanya kesalahan (schuld), dalam hal ini berarti perbuatan pelaku harus mengandung unsur sengaja atau lalai . Perbuatan dapat dipertanggungjawabkan oleh pelaku apabila dalam perbuatan tersebut terdapat unsur kesengajaan atau kelalaian. .Dalam perkara lelang ,kebanyakan penggugat selalu mendalilkan bahwa adanya suatu atau lebih kesalahan (schuld) dalam konteks pembuatan dokumen yang menjadi persyaratan lelang .

\section{Kerugian (schade)}

Syarat yang ketiga adalah adanya kerugian (schade) terhadap korban atau penggugat. Kerugian menurut pasal 1365 Burgerlijk Wetboek Indonesia terbagi dua, yaitu kerugian materiil (kerugian yang diderita oleh seseorang dalam bentuk uang atau benda) dan immaterial (kerugian yang diderita oleh seseorang berupa sesuatu yang tidak dapat dinilai oleh uang seperti nama baik dan sakit). Adanya ganti rugi merupakan hal terpenting dikarenakan jika terdapat kerugian, maka ganti rugi harus dilakukan untuk mengembalikan keadaan seperti semula. Dalam perkara lelang, kerugian biasanya diderita karena adanya penetapan nilai limit yang rendah sehingga menyebabkan objek lelang terjual dengan harga yang tidak wajar.

\section{Kausalitas}

Syarat yang keempat adalah adanya kausalitas atau hubungan sebab dan akibat. Hubungan sebab akibat ini ditujukan kepada hubungan klausal antara perbuatan dan kerugian. Dalam hubungan kausalitas terdapat beberapa teori, yaitu teori hubungan sebab akibat secara proximate causa dan 
secara faktual (caudation in fact) memiliki pengertian bahwa hubungan tersebut merupakan masalah fakta atau sebatas yang secara faktual apa yang telah terjadi dan nyata diderita oleh seseorang (sine qua non)

Untuk memperjelas suatu perbuatan bagaimana yang dapat dinyatakan sebagai perbuatan melawan hukum dan dapat dijadikan sebagai dalil atau faktor pembatalan lelang objek jaminan ,maka dalam hal ini contoh yang akan digunakan adalah penetapan nilai limit yang rendah .Definisi yang didapati dari PMK No.27 Tahun 2016, lelang memiliki definisi: penjualan atas barang yang memiliki sifat terbuka untuk umum dan adanya penawaran harga yang dilakukan secara tertulis maupun lisan untuk mencapai harga tertinggi, pelaksanaan lelang mensyaratkan untuk didahului dengan Pengumuman Lelang. Dalam pelaksaan lelang terdapat juga beberapa syarat yang dalam prosesnya merupakan suatu kewajiban yang harus ada, salah satu diantaranya adalah penetapan nilai limit (harga lelang) objek jaminan yang akan dieksekusi melalui lelang. Nilai limit sendiri memiliki definisi yang tercantum didalam pasal 1 , yaitu :

"Nilai Limit adalah harga minimal barang yang akan dilelang dan ditetapkan oleh Penjual."

Penetapan nilai limit terhadap objek yang akan dieksekusi ditentukan dan merupakan kewajiban penjual untuk menentukan harga lelang dan penetapan harga limit tersebut harus berdasarkan penilaian dari pihak penilai yang independen dan harus sesuai nilai likuidasi (Rianto, 2017). Pejabat Lelang memiliki kewenangang untuk mengesahkan penawar tertinggi sebagai pemenang lelang apabila penawaran yang diajukan telah mencapai harga limit yang ditentukan. Penetapan nilai atau harga limit sendiri merupakan tanggung jawab dari penjual, hal ini sesuai dengan ketentuan pada pasal 17 ayat 1 huruf e PMK, yang berbunyi :

"Penjual bertanggung jawab terhadap: a. keabsahan kepemilikan barang; $b$. keabsahan dokumen persyaratan lelang; c. penyerahan barang bergerak dan/ atau barang tidak bergerak; $d$. penyerahan dokumen kepemilikan kepada Pembeli; dan e. penetapan Nilai Limit. “

Tanggungjawab atas penetapan harga limit dilimpahkan kepada penjual, argumentasi ini sesuai dengan ketentuan pada pasal 44 ayat (4) PMK:

“(1) Penjual menetapkan Nilai Limit, berdasarkan: a. penilaian oleh Penilai; atau b. penaksiran oleh Penaksir. (2) Penilai sebagaimana dimaksud pada ayat (1) huruf a merupakan pihak yang melakukan penilaian secara independen berdasarkan kompetensi yang dimilikinya. (3) Penaksir sebagaimana dimaksud pada ayat (1) huruf b merupakan pihak yang berasal, dari Penjual, yang melakukan penaksiran berdasarkan metode yang dapat dipertanggungjawabkan oleh Penjual, termasuk kurator untuk benda seni dan benda antik atau kuno. (4) Penetapan Nilai Limit sebagaimana dimaksud pada ayat (1) tidak 
menjadi tanggung jawab Kantor Pelayanan Kekayaan Negara dan Lelang atau Pejabat Lelang Kelas II. “

Penetapan nilai atau harga limit haruslah berdasarkan penilaian yang dilakukan oleh penilaiyang bersifat independen. Penilai dapat berupa orang pribadi atau perusahaan terjamin kenetralannya dan professional dalam melaksanakan tugas penilaian, hal ini bertujuan untuk menghindari adanya conflict of interest (konflik kepentingan) terhadap objek yang dinilainya dan penaksiran oleh penaksir yang berasal dari internal pemohon lelang ataupun pemilik barang (Rianto, 2017). Tetapi tidak jarang penetapan nilai atau harga limit terhadap objek jaminan yang akan dieksekusi terlalu rendah dan terdapat perbuatan melawan hukum (onrechtmatige daad) yang dilakukan oleh penjual dalam menentukan nilai limit tersebut. Perbuatan yang termasuk onrechtmatige daad dalam penetapan harga limit yang rendah pada lelang eksekusi dapat digunakan sebagai dasar pertimbangan bagi hakim untuk menentukan onrechtmatige daad yang menjadi faktor pembatalan lelang atas dasar putusan hakim dengan pertimbangan bahwa perbuatan tersebut memenuhi unsur-unsur PMH yang diatur dalam pasal 1365 Burgerlijk Wetboek Indonesia yang menyebabkan kerugian (schade) dan kausalitas atau sebab akibat antara perbuatan dengan kerugian.

Dalam hal ini contoh riil yang dapat digunakan adalah ketika penjual bekerjasama dengan penilai secara melawan hukum dalam menetapkan harga limit yang rendah, dimana perbuatan tersebut dilakukan secara sengaja sehingga karena perbuatannya tersebut menyebabkan adanya pihak yang merasa dirugikan atas perbuatan tersebut. Dari contoh tersebut, dapat dilihat bahwa sebuah onrechtmatige daad dalam pelaksanaan lelang dapat dengan jelas menjadi dasar pertimbangan membatalkan lelang karena tidak memenuhi ketentuan pelaksanaan lelang yang berlaku dan hanya atas dasar putusan hakim. Walaupun pada pasal 4 PMK Nomor 27 Tahun 2016 menyebutkan lelang yang telah dilaksanakan sesuai dengan ketentuan yang berlaku, tidak dapat dibatalkan. Tetapi "tidak dapat dibatalkan "tersebut mengandung syarat "lelang dilaksanakan sesuai dengan ketentuan yang berlaku", sehingga pembatalan lelang yang sudah dilaksanakan tetap dapat dilakukan jika proses pelaksanaan lelang tersebut tidak sesuai peraturan yang berlaku atau melawan hukum.

\section{B. Kajian Yuridis Terhadap Putusan No.274/PDT.G/2013/PN.BDG Dalam Menetapkan Nilai Limit Rendah Sebagai Faktor Pembatalan Lelang Atas Putusan Hakim}

Lelang merupakan upaya pemenuhan hak kreditur yang merupakan kewajiban bagi debitur yang tidak terpenuhi, pelelangan dalam dunia perbankan dilatarbelakangi karena debitur melakukan wanprestasi terhadap kewajibannya 
kepada kreditur, sehingga untuk mendapatkan hak tersebut, kreditur melakukan eksekusi terhadap objek jaminan tersebut. Debitur sendiri sebagai wujud ketidakpuasaan terhadap eksekusi tersebut akan melayangkan gugatan ke Pengadilan untuk membatalkan eksekusi lelang yang dilakukan oleh kreditur. Salah satu dalil yang banyak digunakan oleh debitur untuk menggugat kreditur adalah adanya perbuatan melawan hukum (onrechtmatige daad). Dalil inilah yang kemudian dipertimbangkan oleh hakim dalam memutuskan perkara mengenai jaminan. Ketika perkara ini telah memperoleh keputusan hakim yang inkracht van gewijsde, maka akan timbul suatu akibat hukum dari putusan tersebut yang menyebabkan dibatalkannya lelang atas objek jaminan tersebut, yaitu : akibat hukum terhadap barang lelang, akibat hukum terhadap hak pembeli lelang atas objek jaminan tersebut, akibat hukum penjual terhadap objek jaminan yang dilelang, akibat hukum yang muncul terhadap kewajiban debitur (Riyanto dan Diana, Diponegoro Journal, 2017: 10-11).

Dalam hal ini kita akan menganalisa putusan No.274/ PDT. G/ 2013 / PN.BDG tentang pembatalan lelang eksekusi atas objek hak tanggungan. Adapun dalam kasus posisinya penulis akan menjabarkan para subjek yang terkait. Penggugat 1 bernama Arifin Marahayu selaku pemilik atas objek hak tanggungan yang dijaminkan oleh penggugat II yang bernama Tio Agung Santika Marahayu kepada PT. Bank Mega, Tbk selaku tergugat I yang berperan sebagai penjual dalam lelang dan kreditur. Tergugat II adalah Arief Hidayat selaku pembeli objek lelang hak tanggungan dan tergugat III adalah Kantor Pelayanan Kekayaan Negara dan Lelang Bandung selaku tempat terjadinya pelelangan tersebut.

\section{Kasus posisi}

Penggugat satu merupakan pemilik sebidang tanah dan bangunan terletak di Kota Bandung, Kecamatan Bandung Kidul, Kelurahan Batununggal, Blok Buah Batu Jln. Parakan Arum Nomor 9 yang sekaligus merupakan objek jaminan atas hak tanggungan yang dijaminkan kepada kreditur. Penggugat kedua selaku Debitur yang menjaminkan objek jaminan tersebut kepada PT. Bank Mega (Persero) Tbk yang merupakan tergugat pertama. Penjaminan objek jaminan hak tanggungan itu dimuat dalam suatu perjanjian nomor perjanjian 2312/ PK-SME/ WIL/ BDG/ 11. Akta Pemberian Hak Tanggungan antara penggugat kedua dan tergugat pertama dimuat dalam akta nomor 1178/ 2012 dengan Sertifikat Hak Tanggungan yang dimuat dalam Sertifikat Nomor 16351/ 2012 untuk jaminan utang penggugat kedua kepada tergugat pertama berdasarkan Perjanjian utang piutang dibawah tangan yang dimuat dalam perjanjian No .2312/ PK-SME/ WIL/ BDG/11 dengan nominal sebesar Rp.500.000.000,00. Penggugat kedua dalam perjanjiannya harus membayar utang kepada Tergugat pertama sejumlah Rp.483.000.000,00 sebagaimana yang termuat didalam surat No.282/ Remedial/ RBDG /III/13 yang 
pada pokok isinya memberitahukan akan dilakukan pelelangan dengan nilai atau harga limit barang agunan yang akan dilelang Rp.483.000.000,00 .Dalam APHT Nomor 1178/2012 dan juga dalam Sertifikat Hak Tanggungan dengan Nomor 16351/2012 tercantum Hak Tanggungan diberikan kepada debitur atau penggugat kedua untuk jaminan pelunasan piutang kepada tergugat pertama dengan nominal Rp.625.000.000,00 , nominal angka Rp.625.000.000,00 merupakan 70\% (tujuh puluh persen) dari nilai taksir objek hak tanggungan (nilai taksir objek adalah Rp.812.500.000,00) yang dijaminkan oleh tergugat pertama, sehingga harga pasar yang sebenarnya atas objek hak tanggungan milik Penggugat pertama adalah diatas Rp.812.500.000,00 berdasarkan nilai taksir yang penaksirannya dilakukan oleh kreditur atau tergugat pertama .

NJOP pada objek jaminan milik Penggugat pertama tersebut diketahui adalah sebesar Rp.755.297.000,00. Kemudian berdasarkan surat Tergugat pertama kepada Penggugat kedua memiliki isi yang pada pokoknya memberitahukan pelelangan terhadap objek jaminan akan dilakukan dengan penetapan harga limit sebesar Rp.483.000.000,00. Tentu saja harga limit tersebut jauh berada di bawah harga pasar atau harga dan tidak menganut asas kepatutan dan kewajaran sesuai dengan NJOP dari objek yang dilelangkan tersebut. Dan oleh tergugat ketiga atau KPKNL telah dilaksanakan pelelangan pada tanggal 21-03-2013 dengan harga limit lelang tersebut adalah Rp.483.000.000,00. Pelelangan tersebut kemudian dimenangkan oleh Tergugat kedua selaku pembeli objek lelang. Harga limit lelang tersebut tentu saja bernilai lebih kecil dari NJOP tanah dan bangunan milik Penggugat pertama, sehingga penentuan nilai atau harga limit yang dilakukan oleh Tergugat pertama dengan bantuan penilai yang independen tidak memenuhi dan sekaligus melanggar ketentuan PMK No.93/PMK.06/2010 karena Tergugat pertama telah menunjukkan sifat tidak professional dalam menentukan harga limit yang seharusnya harga limit tersebut seminimalnya sesuai dengan NJOP atas objek lelang pada tahun 2013 yaitu Rp.755.297.000,00 . Dan oleh karenanya Tergugat pertama dinyatakan telah melanggar hukum karena pelaksanaan lelang tersebut tidak sesuai dan melanggar ketentuan Pasal 35 dan pasal 36. Jika kita hitung seksama, berdasarkan pengurangan atas NJOP pelelangan tanah dan bangunan terhadap harga limit dalam pelelangan tersebut, maka penggugat menderita kerugian sebesar Rp.272.297.000,00.

Dalam hal ini penulis akan melakukan analisa terkait $\mathrm{PMH}$ (onrechtmatige daad) dalam penetapan nilai atau harga limit yang rendah dan tidak sesuai dengan NJOP dari objek lelang tersebut. Pertama kita akan melakukan analisis terkait kasus posisi dengan pasal 1365 BW Indonesia yang berbunyi:

"Tiap perbuatan yang melanggar hukum dan membawa kerugian kepada orang lain, mewajibkan orang yang menimbulkan kerugian itu karena kesalahannya untuk menggantikan kerugian tersebut." 
Syarat-syarat yang harus dicermati dalam menentukan adanya perbuatan melawan hukum (onrechtmatige daad) dalam penetapan harga limit yang terlalu rendah adalah dengan mencari unsur dari onrechtmatige daad.

\section{Perbuatan yang melawan hukum oleh tergugat}

Pertama kita akan mengkaji apakah terdapat perbuatan yang melawan hukum didalam tindakan kreditur. Kreditur awalnya berdalih bahwa mereka telah melaksanakan semuanya sesuai dengan proses lelang yang diatur di dalam PMK No.93/PMK.06/2010 (yang kemudian di ubah menjadi PMK Nomor 27/PMK.06/2016) pasal 44 yang berisi:

"Pengumuman Lelang untuk Lelang Eksekusi terhadap barang tidak bergerak atau barang tidak bergerak yang dijual bersama-sama dengan barang bergerak, dilakukan dengan ketentuan sebagai berikut:

a. $\quad$ pengumuman dilakukan 2 (dua) kali, jangka waktu Pengumuman Lelang pertama ke Pengumuman Lelang kedua berselang 15 (lima belas) hari dan diatur sedemikian rupa sehingga Pengumuman Lelang kedua tidak jatuh pada hari libur/hari besar;

b. pengumuman pertama diperkenankan tidak menggunakan surat kabar harian, tetapi dengan cara pengumuman melalui selebaran, tempelan yang mudah dibaca oleh umum, dan/atau melalui media elektronik termasuk Internet, namun demikian dalam hal dikehendaki oleh Penjual, dapat dilakukan melalui surat kabar harian; dan

c. Pengumuman kedua harus dilakukan melalui surat kabar harian dan dilakukan paling singkat 14 (empat belas) hari sebelum pelaksanaan lelang. "

Fokus kita hari ini terletak pada objek jaminan berupa tanah yang diikatkan hak tanggungan, sehingga tanah termasuk dalam lelang eksekusi yang menurut delik pasal 44 PMK, lelang eksekusi harus dicantumkan dalam pengumuman lelang . Awal mulanya kreditur atau tergugat I berdalih bahwa mereka telah memberikan pengumuman lelang kepada penggugat II, tetapi setelah majelis meminta bukti pengumuman lelang tersebut, tergugat I tidak dapat membuktikan adanya pengumuman lelang yang mereka dalihkan sebelumnya. Dalam hal ini jelas bahwa perbuatan yang dilakukan oleh tergugat I yang dalam hal ini melelang objek jaminan hak tanggungan tanpa didahului pengumuman lelang adalah perbuatan yang melawan hukum karena tidak sesuai dengan pasal 44 Peraturan Menteri Keuangan (PMK) No.93/PMK.06/2010. Selain itu penggugat sebelumnya menyatakan nilai Hak tanggungan sebesar Rp.625.000.000,00 dan harga limit yang ditentukan oleh Tergugat I adalah sebesar Rp.483.000.000,00, penetapan harga limit tersebut terlalu rendah sehingga melanggar ketentuan PMK No.93/PMK.06/2010 karena Tergugat I telah tidak kompeten dan tidak professional dalam menentukan nilai limit yang seharusnya menimal sesuai dengan 
NJOP 2013 yaitu Rp.755.297.000,00 oleh karenanya Tergugat I telah melanggar hukum dengan melanggar ketentuan Peraturan Menteri Keuangan No.93/PMK.06/2010 tentang Petunjuk Pelaksanaan Lelang Pasal 35 dan pasal 36.

\section{Kesalahan yang mengandung unsur kesengajaan oleh tergugat}

Syarat kedua yang akan kita tinjau adalah apakah terjadi kesalahan yang di dalamnya termuat unsur kesengajaan dan kelalaian. Kesalahan ini dapat kita tinjau dari penetapan nilai limit yang rendah sehingga tidak memuat unsur kewajaran, padahal kreditur sejatinya pernah menanyakan harga dari objek jaminan tersebut kepada Penggugat 1 dan kreditur (Tergugat II) mengetahui dengan jelas bahwa nilai jual dari objek jaminan tersebut melebihi dari penetapan nilai limit yang ditetapkan penjual, yaitu Rp.483.000.000,00. Tergugat pertama dalam menetapan nilai limit dalam lelang yang diadakan di KPKNL tersebut tidak dapat membuktikan bahwa penetapan nilai atau harga limit sebesar Rp. 483.000.000,00 berdasarkan penilaian dari pihak tergugat I yang dapat dipertanggung jawabkan.

\section{Kerugian materiil yang diderita oleh penggugat}

Syarat ketiga untuk menentukan bahwa penetapan nilai limit yang rendah tersebut merupakan perbuatan melawan hukum, maka kita akan mencari unsur kerugian yang diderita oleh debitur atau penggugat. Dalam hal ini penggugat menderita kerugian dikarenakan nilai jual objek pajak dari objek jaminan tersebut adalah Rp.755.297.000,00 dan nilai likuidasi dari objek tersebut adalah sebesar Rp.888.440.000,00. Sedangkan nilai limit yang ditetapkan dalam pelelangan tersebut hanya sebesar Rp. 483.000.000,00 yang tentu saja jauh dari kesimpulan penilai dan sangat merugikan pihak penggugat yang dalam hal ini adalah debitur secara materiil.

\section{Kausalitas}

Syarat terakhir yang akan kita lihat adalah ada tidaknya unsur sebab akibat dari perbuatan kreditur yang menetapkan harga limit sebesar 483 juta rupiah yang jauh dari nilai jual objek pajak sebesar Rp. 1.269.200.000 yang menyebabkan kerugian bagi pihak debitur, dalam hal ini tentu saja terdapat hubungan sebab akibat, yaitu dikarenakan pelelangan yang diadakan oleh kreditur yang merupakan perbuatan melawan hukum, mengakibatkan bagi debitur kerugian materiil yang besar.

\section{Akibat Hukum}

Berdasarkan analisa Putusan No 274/ PDT.G/ 2013 /PN.BDG, hakim dalam putusannya memutuskan bahwa tergugat pertama, kedua dan ketiga melakukan perbuatan melawan hukum, sehingga pelaksanaan lelang tersebut merupakan tidak sah dan tidak memiliki kekuatan hukum yang mengikat. Akibat yang ditimbulkan bagi para pihak tergugat berdasarkan putusan hakim tersebut adalah dibatalkannya 
Risalah lelang Nomor 111/2013 karena tidak sah dan tidak memiliki kekuatan hukum yang mengikat karena pelaksanaan lelang tersebut tidak sesuai dengan PMK No.93/PMK.06/2010 dan oleh karenanya akibat hukum bagi:

\section{a. Hak kepemilikan objek yang telah dibeli melalui lelang}

Kepemilikan atas objek lelang tersebut kembali kepada keadaan semula dalam kondisi ini objek lelang tersebut kembali kepemilikannya kepada debitur selaku penggugat tetapi status objek tersebut tetap berada dalam keadaan sebagaimana status barang tersebut sebelum lelang dilaksanakan yaitu tetap berada dibawah hak tanggungan yang dipegang oleh kreditur atau tergugat pertama.

\section{b. Hak tergugat kedua selaku pembeli objek lelang}

Hak pembeli objek lelang atau tergugat kedua atas objek lelang yang telah dibeli akan berakhir pada saat dikeluarkannya putusan hakim dan kembali penguasaannya kepada kreditur atau tergugat pertama.

\section{c. Hak tergugat pertama selaku penjual}

Tergugat pertama selaku penjual tidak memiliki hak atas pemenuhan kewajiban tereksekusi lelang atas barang objek lelang. Sehingga tergugat pertama harus mengembalikan hasil lelang kepada tergugat kedua selaku pembeli objek lelang dan objek lelang tersebut kembali ke status barang jaminan.

\section{d. Kewajiban penggugat pertama}

Utang penggugat kedua selaku debitur kembali dalam posisi semula, sehingga tergugat pertama memiliki piutang seperti yang diperjanjikan dalam surat perjanjian 2312/ PK- SME/ WIL/ BDG / 11 terhadap penggugat kedua.

\section{PENUTUP}

1. Perbuatan melawan hukum merupakan salah satu faktor yang dapat menyebabkan pembatalan lelang eksekusi objek jaminan atau dalam hal ini lebih berfokus kepada objek hak tanggungan yang berupa tanah dan bersifat barang tidak bergerak. Dalam menentukan adanya perbuatan melawan hukum, kita harus mengkaji berdasarkan pasal 1365 Kitab Undang-Undang Hukum Perdata Indonesia terlebih dahulu dan mengkaji apakah dalam perbuatan tersebut terpenuhi 4 unsur sebagai syarat suatu perbuatan dinyatakan sebagai perbuatan melawan hukum, syarat-syarat tersebut adalah daad, schuld, schade, causality. Contoh riil mengenai PMH (onrechtmatige daad) dalam perkara lelang adalah penetapan nilai limit yang rendah dan tidak sesuai peraturan perundang-undangan yang menyebabkan 
dibatalkannya lelang eksekusi objek jaminan tersebut atas dasar putusan hakim.

2. Putusan Mahkamah Agung No 274 Tahun 2013 merupakan putusan yang didalamnya penggugat mendalilkan tergugat melakukan perbuatan melawan hukum (onrechtmatige daad) dalam penetapan nilai limit objek lelang yang dalam putusannya majelis hakim berdasarkan pertimbangan-pertimbangan memutuskan bahwa risalah lelang tersebut tidak sah dan risalah lelang tersebut juga tidak memiliki kekuatan hukum yang mengikat dikarenakan perbuatan tergugat memenuhi keempat unsur perbuatan melawan hukum ,sehingga risalah lelang atas objek jaminan tersebut dibatalakan atas dasar putusan Majelis Hakim dalam putusan tersebut . Akibat hukum yang timbul dari pembatalan lelang tersebut adalah kembalinya keadaan seperti semula baik dari kepemilikan objek, kepenguasaan objek, hak dan kewajiban masing- masing pihak seperti pada saat belum terjadinya pelelangan atas objek tersebut.

\section{DAFTAR PUSTAKA}

\section{Buku}

Fuady, Munir. 2013. Perbuatan Melawan Hukum-Pendekatan Kontemporer. Citra Aditya Bakti. Bandung.

Patrik , Purwahid \& Kashadi . 2009 . Hukum Jaminan. Badan Penerbit Universitas Diponegoro Semarang. Semarang .

Volmar, H. F. A .2004 . Pengantar Study Hukum Perdata . Rajawali Pers ,Jakarta.

\section{Jurnal}

Diana, A. H., \& Benny Riyanto, M. (2017). Upaya Pembatalan Lelang Eksekusi Hak Tanggungan Akibat Kredit Macet . Diponegoro Law Journal, 6 (1).

Rianto, R. D. (2017). Kajian Yuridis Pembatalan Lelang Eksekusi Karena Nilai Limit Rendah. Kumpulan Jurnal Mahasiswa Fakultas Hukum.

Prayogo, Sedyo .2016. Penerapan Batas-Batas Wanprestasi dan Perbuatan Melawan Hukum dalam Perjanjian. Jurnal Pembaharuan Hukum ,3 (2).

Febriliana, M. 2017. Perbuatan Melawan Hukum, Universitas Sumatera Utara .

\section{Artikel Online}

Khalim, Abdul .2014. Perbuatan Melawan Hukum dalam Gugatan Pelaksanaan Lelang di KPKNL . Artikel DJKN.

\section{Putusan dan Peraturan Perundang-Undangan}

Putusan Mahkamah Agung Nomor 274/ PDT.G/ 2013 /PN.BDG 
Peraturan Menteri Keuangan No.93/PMK.06/2010 tentang Petunjuk Pelaksanaan Lelang

Peraturan Menteri Keuangan Nomor 27/PMK.06/2016 tentang Pelaksanaan Lelang 